\title{
Timing of surgery for benign periacetabular tumor: virtual finite element analysis and clinical verification on 39 cases
}

\section{Hongsheng Yang}

Sichuan University West China Hospital

\section{Wenli Zhang}

Sichuan University West China Hospital

\section{Yun Lang}

Peoples Hospital of Deyang City

\section{Xiang Fang}

Sichuan University West China Hospital

Duan Hong ( $\nabla$ duanhong1970@126.com )

Sichuan University West China Hospital https://orcid.org/0000-0001-9430-5937

\section{Research}

Keywords: Acetabular dome, Benign tumor, Bone defects, Finite element analysis, Pelvis

Posted Date: October 8th, 2020

DOI: https://doi.org/10.21203/rs.3.rs-84945/v1

License: (c) (i) This work is licensed under a Creative Commons Attribution 4.0 International License. Read Full License 


\section{Abstract}

\section{Background}

The treatment of periacetabular tumor has always been met with great challenges, including the lack of a standard for the timing of surgery. The purposes of this study were to predict the risk for fracture by finite element analysis of benign periacetabular tumor; to guide the timing of operation; and to verify the practical application of this standard through clinical cases.

\section{Methods}

Bone defects in different areas of the acetabulum were constructed, and the fracture risk was predicted by finite element analysis. According to the results of finite element analysis and Enneking classification, the patients with benign periacetabular tumor were divided into the low fracture risk noninvasive lesion, low fracture risk invasive lesion, and high fracture risk groups. The grouping was used to guide the timing of operation.

\section{Results}

This study included 39 patients who were followed-up for at least two years to verify the effectiveness of this program. The 12 patients in the low risk noninvasive lesion group that did not undergo operation showed no obvious pathological changes and no pathological fracture; there was no significant difference in the MSTS-93 score between the first and last visits $(P>0.05)$. The 7 patients in the low risk invasive lesion group were treated with adjuvant therapy before the operation; the MSTS-93 score was significantly lower on the first visit than on the last visit $(P<0.05)$. The 20 cases that had high risk for fracture underwent surgery after the diagnosis; of these, 13 patients achieved osseointegration of the graft bone and 7 patients had no prosthesis loosening, detachment, displacement or rupture after prosthesis replacement. The MSTS-93 score significantly improved from a preoperative value of $19.61 \pm 7.32$ to a final follow-up value of $26.28 \pm 15.59(P<0.01)$.

\section{Conclusions}

Our study confirmed that for benign periacetabular tumor, finite element analysis, combined with the nature of the tumor, can predict the risk for acetabular fracture and guide the appropriate timing and method of operation, thereby, enabling a safe therapeutic effect.

\section{Background}

The diagnosis and treatment of acetabular bone tumors has always been a great challenge for bone oncologists [1-3]. Often, several postoperative complications may occur because of the deep location; complex anatomical structures; and the adjacent important nerves, vessels, and organs [4-6]. For malignant bone tumors in this area, surgeons often choose wide resection and reconstruction [7-9]. However, some benign periacetabular tumors are common in this area; some examples are giant cell tumor of the bone, fibrous dysplasia, bone cyst, chondroblastoma, and Langerhans cell dysplasia [1, 5, 6, 10]. For benign periacetabular tumors of different Enneking grades, unified standards on the assessment of fracture risk and timing of operation are lacking $[2,6$, 11-14]. The dome of the acetabulum is the weight-bearing part of the articular surface and supports the femoral head; tumors in this area will decrease bone strength. In usual clinical practice, most surgeons make the diagnosis and treatment decisions based on experience. Finite element analysis (FEA) has been successfully applied in 
orthopedics and can be a good tool for studying the mechanics of irregular bone structures. In the past, biomechanical analysis of the pelvis has mostly aimed at the normal pelvis, fracture model, and artificial prosthesis replacement model after tumor resection [15-17]. There had been no reports on the biomechanical analysis of benign neoplastic bone defects in the acetabulum. Therefore, this study aimed to establish an acetabular top bone defect model and to perform mechanical analysis for the evaluation of fracture risk in the periacetabular bone defect caused by a benign bone tumor, in order to guide the timing of operation.

\section{Methods}

In this study, we constructed a simulated model of neoplastic bone defects in different areas on top of the acetabulum. The fracture risk was predicted by three-dimensional (3D) FEA, the results of which were used to divide patients into the low fracture risk and high fracture risk groups and to guide the timing of surgical treatment of 39 patients with benign acetabular bone dome tumors. Clinical follow-up was performed for at least two years.

\section{Finite element analysis}

At the beginning of the study, we established a static biomechanical 3D finite element model of a neoplastic bone defect caused by a benign bone tumor on the top of the acetabulum using thin-slice CT scans from May 2014 to October 2014. Stress loading was carried out in the following positions: sitting, standing on two feet, standing on one foot on the affected side, and simulated one foot jumping state. The magnitude and distribution of stress in each model were analyzed. The fracture risk of the benign acetabular dome bone defect was evaluated based on biomechanics, and the decision-making on clinical diagnosis and treatment was further guided using this model.

The CT scan DICOM data of the normal pelvis of one patient (26 years old, $173-\mathrm{cm}$ tall, $60 \mathrm{~kg}$ in weight) were imported into Mimics V15.0 software for 3D reconstruction and to simulate a normal pelvis and proximal femur model. According to the gray value of the CT image, the property of the bone material was assigned in Mimics as cortical bone elastic modulus of $17-G p a$, Poisson's ratio of 0.3 , and fatigue strength of 150 Mpa for the upper and lower pubic area and $120 \mathrm{MPa}$ for the acetabular area. Different types of acetabular dome bone defect models were simulated in Mimics. All parts were imported into ABAQUS 6.13 for assembly and meshing. The nodes and element number of each model are shown in Table 1.

There are six types of bone defect located 5-mm away from the acetabular dome. In type I, the anterior column is resected above the inferior margin of the acetabulum in the pelvic AP position. In type II, the posterior column is resected above the superior margin of the acetabulum in the pelvic AP position. In type III, 50\% of the anterior column is resected at the medial part of the acetabulum dome and connected to the posterior column above the lower edge of the acetabulum. In type IV, the anterior column of the acetabulum is resected and connected to $50 \%$ of the posterior column. In type $\mathrm{V}, 50 \%$ of the anterior column and $50 \%$ of the posterior column are resected and connected to the acetabular dome. In type $\mathrm{VI}$, the entire anterior and posterior columns of the acetabulum dome were removed) (Fig. 1).

The six types of bone defects in four different positions were analyzed in a software; the positions were sitting, standing, affected one-legged standing, and affected one-legged jumping. In reference to previous studies [18-20], a vertical downward load of $500 \mathrm{~N}$ was imposed on the surface of the sacrum to simulate the gravity of the upper part of the body. The loading power of the stress was $500 \mathrm{~N}$ in the sitting, standing, and affected one-legged standing positions and $1000 \mathrm{~N}$ on the affected acetabular dome to stimulate a one-legged jumping position. 
Based on the previously reported fatigue strength of 120-150 Mpa for the pelvic cortical bone, the acetabular fatigue strength in this study was set as $120 \mathrm{Mpa}$.

The fracture risk of the acetabulum dome was evaluated by FEA, which showed results that are described in the next sentences. In the normal pelvic model, the maximum stress was $1.5 \mathrm{MPa}$ on the sciatic tuberosity in the sitting position; 0.6 MPa on the superior border of the greater sciatic notch in the standing position; and $3.5 \mathrm{MPa}$ on the upper edge of the greater sciatic notch in the affected one-legged standing position. Among all the positions in the six different types of bone defects, the maximum stress was observed in the affected one-legged jumping position. The maximum stress values of 22.8, 36.0, 40.6, and 30.9 Mpa in the type I, II, III, and V bone defect models, respectively, were far less than the acetabular fatigue strength of $120 \mathrm{Mpa}$. The maximum stress values of 106.7 Mpa and 114.0 Mpa in the type IV and VI bone defect models, respectively, were close to the acetabular fatigue strength value that was at risk for fracture (Fig. 2).

According to the predicted fracture risk outcome of the top of the acetabulum, we divided the bone lesions into the following two groups: the low fracture risk group, which included type I, II, III, and V bone defect models, and the high fracture risk group, which included type IV and VI bone defect models.

\section{Clinical verification}

Our study was approved by the institution research ethics board, and informed consent was obtained from all patients. The inclusion criteria were 1) patients with acetabular lesions that mainly involved the acetabular dome and 2) benign bone tumor that was pathologically-proven or highly suspected by the doctor based on symptoms, medical history, and ancillary examination. The exclusion criteria were 1) malignant tumor; 2) pelvic tumor that did not involve the acetabular dome; 3) pelvic lesions that caused severe clinical symptoms and involved the acetabulum, which needed simultaneous surgical treatment; and 4) pathological fractures on the first visit. From January 2015 to July 2018, a consecutive series of patients seen at our institution for benign bone tumors on the acetabulum dome were enrolled in this study.

First, the range of acetabular fornix involved in each patient was divided, based on the results of CT and MRI. The patients were divided into the low and high fracture risk groups, according to the results of the FEA. According to clinical evaluation of the doctor, the low fracture risk group was further divided into the invasive lesion group (Enneking III) or the noninvasive lesion group (static or active lesion, Enneking I and II). The high fracture risk group was not further divided. Finally, all patients were divided into the following three groups: low fracture risk noninvasive lesion, low fracture risk invasive lesion, and high fracture risk groups.

The low fracture risk noninvasive lesion group was followed-up in the outpatient clinic. The following were recorded on the first visit: initial diagnosis of the doctor, acetabular lesion site, and Musculoskeletal Tumor Society Score-93 (MSTS-93) [21]. Subsequently, the patients were followed-up every three months by CT or MRI, according to the doctor's discretion. The main outcome measures were acetabular lesion changes, MSTS-93, and occurrence of pathological fracture. Operation was immediately performed if there was obvious progression of the lesion or pathological fracture of acetabular dome.

Likewise, the low fracture risk invasive lesion group was followed-up in the outpatient clinic. On the first visit, the patient diagnosis, lesion site (acetabular involvement), and MSTS-93 were recorded. The operation was not arranged temporarily, activity was not restricted, and adjuvant therapy with bisphosphonate intravenous injection or dinosemide was administered, according to diagnosis. The patients were examined every two to three months 
with CT or MRI examination, according to the doctor's discretion. Changes in the lesions and occurrence of pathological fractures were assessed during each follow-up, and MSTS-93 functional score was recorded on the last follow-up. Operation was performed at the end of the adjuvant treatment or when the lesion changed and became at high risk for fracture, based on the FEA.

The high fracture risk group was examined and underwent surgical treatment after diagnosis. The surgical treatments included the following: 1) curettage with bone grafting or bone cement; 2) tumor resection, total hip replacement, and acetabulum reconstruction with the femoral head; or 3) tumor resection with modular hemipelvic replacement.

\section{Statistical analysis}

Continuous data were expressed as mean \pm standard deviation. The normality of continuous data was tested by the one sample Kolmogorov-Smirnov test. Normally distributed parameters were analyzed by the independent sample t-test, and nonnormally distributed parameters were analyzed by the Mann-Whitney U-test. A P value of $\leq 0.05$ was considered statistically significant. Statistical analysis was performed by SPSS Statistics software version 23.0 (IBM, Armonk, NY).

\section{Results}

The study included a total of 39 patients with a mean age of 42.4 years (14-60 years); 26 were men and 13 were women. The median follow-up period was $33.36 \pm 11.41$ months (24-67 months).

As shown in Table 2, the low risk noninvasive lesion group comprised 12 cases that did not undergo operation. All patients did not undergo pathological examination but were clinically diagnosed by doctors as fibrous dysplasia ( $\mathrm{n}$ $=5)$, simple bone cyst $(n=4)$, and unknown $(n=3)$. During the follow-up period, there were no obvious pathological changes and pathological fractures in all patients. There was no significant difference in the MSTS93 score between the first and last visits $(P>0.05)$.

Table 3 shows the data of the patients in the low risk invasive lesion group. There were seven cases that were pathologically diagnosed as giant cell tumor of the bone $(n=3)$, aneurysmal bone cyst $(n=3)$, and giant cell tumor of the bone with aneurysmal bone cyst $(n=1)$. All patients were treated with adjuvant therapy; four cases were treated with bisphosphonate intravenous infusion for 3-4 times and the remaining three cases were treated with dinosemide infusion. The operation performed was enlarged curettage of the focus and inactivated bone grafting in the tumor cavity. One case of giant cell tumor of the bone with recurrent aneurysmal bone cyst had a recurrence rate of $14.29 \%$. The MSTS-93 score was significantly lower on the first visit than on the last visit $(P<0.05)$. The pathological results in all patients were confirmed after operation.

There were 20 cases in the high fracture risk group. The diagnoses were fibrous dysplasia $(n=6)$, hemangioma (n $=3)$, Langerhan's cell hyperplasia $(n=1)$, aneurysmal bone cyst $(n=3)$, giant cell tumor of the bone with aneurysmal bone cyst $(n=3)$, chondroblastoma $(n=1)$, diffuse giant cell tumor of the tendon sheath $(n=1)$, and giant cell tumor of the bone $(n=2)$. No distant metastasis was observed after surgery. One case of giant cell tumor of the bone developed local recurrence on the second year after the operation and was treated with extended resection, whereas the other case of giant cell tumor of the bone recurred one year after the operation and was cured by reoperation. The case of diffuse giant cell tumor of the tendon sheath was cured at three months after two-stage reconstruction of the right hip joint. One case had bilateral pleural effusion after the operation. For the 
surgical incision site, exudate developed in 4 cases; redness and swelling developed in 2 cases and healed after standard dressing change and antibiotics; fat liquefaction developed in 2 cases and healed after standard dressing change. In 13 patients who underwent curettage and bone grafting, osseointegration of the graft bone and satisfactory bone strength of the acetabular dome on X-ray were achieved at 12-15 months after the operation. In seven patients who underwent tumor resection and prosthesis replacement, there was no prosthesis loosening, detachment, displacement, or rupture observed. The MSTS score significantly improved from a mean preoperative value of $19.75 \pm 6.47$ to a final follow-up value of $26.30 \pm 4.35(\mathrm{P}<0.01)$. The data of the patients in high fracture risk group are recorded in Table 4.

\section{Discussion}

The treatment of bone tumors on the acetabular dome remains a challenge. Moreover, assessment of the nature of the tumor and the risk for pathological fracture had been difficult. Based on previous studies, there are no clear criteria for the diagnosis of pathological fractures of the acetabular fornix. However, most scholars believe that there are many postoperative complications that are difficult to avoid because of the complexity of the operation [18-20]. For pathological fracture risk assessment of metastatic tumors, a Mirels score of $\geq 8$ implies a high probability of fracture and is an indication for preventive surgery [21]. One study by Damron $T$ et al reported that the prediction of metastatic fractures was more accurate by CT-based structural stiffness analysis than by the Mirels scoring system [22]. However, there has been no risk prediction model for benign tumors of the acetabulum, and the treatment strategy for these lesions remains to be further explored.

In this study, based on the Judet-Letournel classification system, a defect model located $5 \mathrm{~mm}$ from the center of the acetabular dome was established by FEA. A 3D FEA of acetabular tumors was carried out to provide scientific data on the stress concentration in the model of a benign bone defect on the top of the acetabulum from the aspect of biomechanics, in order to predict the risk of fracture. To our best knowledge, this has not been previously reported. Our FEA results showed a relatively low fracture risk for lesions in a single anterior or posterior column; lesions that involved $50 \%$ of the anterior column and the posterior column; and lesions that involved $50 \%$ of the anterior column and $50 \%$ of the posterior column on the top of the acetabulum. On the other hand, there was a high risk for pathological fracture when there was involvement of both columns or involvement of the anterior column and $50 \%$ of the posterior column.

Among patients who were at low risk for fracture, those who had noninvasive lesions achieved satisfactory results with nonoperative treatment, probably because of the limited scope and the little impact on the stability of the acetabular bone; whereas those who had invasive lesions needed surgical treatment with appropriate adjuvant therapy, when needed. In the latter group, the patients were advised to continue their normal activities, in order to reduce the risk for recurrence and decreased the difficulty of the operation; all patients in this group recovered well and achieved high tumor control after surgical treatment and complete adjuvant therapy. For patients at high risk for fracture, regardless of the nature of the tumor, surgery should be chosen to prevent pathological fractures, which can make the operation more difficult, and to reduce the risk of tumor recurrence.

Invasive benign tumors, such as giant cell tumor of the bone or chondroblastoma, usually require surgical treatment, because they have a progressive growth $[8,23]$. Regardless of the risk of fracture, these tumors are surgically removed and treated with intraoperative local adjuvant agents. Tumor resection, bone graft reconstruction, and artificial joint replacement may result in complete removal of the tumor but can lead to many complications [10, 24-27]. In order to reduce the risk of complications, improve function, shorten operation time, 
and reduce surgical injury, other aspects may need to be considered. As shown in this study, further improvements in the level of diagnosis and exploration of new auxiliary treatment measures, such as the treatment of low risk invasive tumors, may serve this purpose. In addition, for patients who need prosthesis replacement, improving the prosthesis design has always been the direction of clinicians' efforts. According to the preoperative CT and MRI image data, a 3D printed pelvic tumor model and an osteotomy guide plate were established to simplify the operation procedure and to obtain a more accurate operation boundary. Personalized 3D printed prosthesis was reported to improve individual matching and functional results and will be the future development direction [2829].

\section{Limitations}

Because of the lack of micro-CT and further computer hardware support, the model established in the present study failed to accurately simulate the cancellous bone and reconstruction of the surrounding pelvic muscles. Among the three static pelvic positions, the affected leg standing position had the greatest stress and accounted for only $81 \%$ of the body weight. On steady walking, pelvic stress can reach $4-7$ times the maximum weight (4 times the weight upon heel landing, 7 times the weight before toe lifting); as the walking becomes faster, the stress increases. When running and jumping, the maximum weight is up to 10 times. Therefore, stress analysis on the bone defect models in this study failed to predict all pathological fracture risks. Moreover, because bone strength is significantly lower in an actual pelvis than in a healthy pelvis, the stress analysis in this study may have underestimated the risk of fracture. During postoperative functional exercise, the stress on the pelvis is 1.5 times as much as that of the body when raising a straight leg. In order to know the safety of a functional exercise, the stress on the pelvis on straight leg raising should be analyzed.

For the clinical case verification, only 39 patients were included in this study; this may have created a selection bias that would limit the generalizability of the present results. A larger sample size may have led to more significant univariate associations. Our study ignores the type of disease and the nature of the tumor, which has a certain impact on the results. The focus was divided according to the acetabulum defects locations, which were not further compared; this may have affected the final results of the experiment to a certain extent. In patients who did not undergo surgery, some of the clinical diagnosis of the doctors may have been inaccurate. Because of the limitations of the follow-up time, the long-term changes in the lesions were not known. All these limitations were important factors that may have led to biases in this study.

\section{Conclusions}

The results of this study confirmed that for benign periacetabular tumors, 3D FEA combined with the nature of the tumor may predict the risk for acetabular fracture and guide the decisions on the appropriate timing and method of operation. These would lead to more safe therapeutic effects.

\section{Abbreviations}

FEA, finite element analysis; MSTS-93, Musculoskeletal Tumor Society Score 93; CT, computed tomography; GCT, giant cell tumor; MRI, magnetic resonance imaging

\section{Declarations}




\section{Availability of data and materials}

The datasets used and analyzed during the current study are available from the corresponding author on reasonable request.

\section{Ethics approval and consent to participate}

This study has been approved by the Biomedical Ethics Committee of West China Hospital of Sichuan University, approval No. 2014 (189).

\section{Consent for publication}

Written informed consent was required from all patients before the start of the study.

\section{Competing interests}

The authors declare no conflicts of interest.

\section{Funding}

There was no fundamental support in this study.

\section{Authors' contributions}

HY: designed the study, collected and analyzed the data, prepared the manuscript. WZ: collected and analyzed the data, prepared the manuscript. YL: collected and analyzed the data, prepared the manuscript. XF: prepared the manuscript. All authors read and approved the final manuscript and agreed to be accountable for all aspects of the work.

\section{Acknowledgements}

We would like to express our gratitude to Professor Wentao Jiang of the Department of Architecture and Environment, Sichuan University for the help on the 3D FEA of this study.

\section{References}

1. Wang B, Hao Y, Pu F, Jiang W, Shao Z. Computer-aided designed, three dimensional-printed hemipelvic prosthesis for peri-acetabular malignant bone tumour. Int Orthop. 2018;42:687-94.

2. Bus MP, Boerhout EJ, Bramer JA, Dijkstra PD. Clinical outcome of pedestal cup endoprosthetic reconstruction after resection of a peri-acetabular tumor. Bone Joint J. 2014;96-B:1706-12.

3. Wang B, Sun P, Xie X, Wu W, Tu J, Ouyang J, et al. A novel combined hemi pelvic endoprosthesis for periacetabular tumours involving sacroiliac joint: a finite element study. Int Orthop. 2015;39:2253-9. 
4. Unni KK. Dahin's bone tumors: general aspects and data on 10165 cases, 6th edition. Philadelphia: Lippincott Williams \& Wilkins. 2009:5-8.

5. Carter SR, Eastwood DM, Grimer RJ, Sneath RS. Hindquarter amputation for tumors of the musculoskeletal system. J Bone Joint Surg Br. 1990;3:490-3.

6. Campanacci D, Chacon S, Mondanelli N, Beltrami G, Scoccianti G, Caff G, et al. Pelvic massive allograft reconstruction after bone tumour resection. Int Orthop. 2012;36:2529-36.

7. Puchner SE, Funovics PT, Böhler C, Kaider A, Stihsen C, Hobusch GM, et al. Oncological and surgical outcome after treatment of pelvic sarcomas. PLoS One. 2017;12:e0172203.

8. Zhang Y, Guo W, Tang X, Yang R, Ji T, Yang Y, et al. En bloc resection of pelvic sarcomas with sacral invasion: a classification of surgical approaches and outcomes. Bone Joint J. 2018;100-B:798-805.

9. Wan ZH, Huang ZH, Chen LB. Survival outcome among patients with Ewing's sarcoma of bones and joints: a population-based cohort study. Sao Paulo Med J. 2017;136(2):116-22.

10. Sherman CE, O'Connor MI, Sim FH. Survival, local recurrence, and function after pelvic limb salvage at 23 to 38 years of followup. Clin Orthop Relat Res. 2012;470:712-27.

11. Wang GY, Zhang CC, Xu SG, Ren K. Establishment of a three-dimensional finite element model of acetabular by using DICOM data. J Clin Rehab Tissue Eng Res. 2007;11:111-4.

12. Wang W, Bi WZ, Yang J, Han G, Jia JP. Pelvic reconstruction with allogeneic bone graft after tumor resection. Acta Ortop Bras. 2013;21:150-4.

13. Ando K, Heymann MF, Stresing V, Mori K, Rédini F, Heymann D. Current therapeutic strategies and novel approaches in osteosarcoma. Cancers (Basel). 2013;5:591-616.

14. Enneking WF, Dunham WK. Resection and reconstruction for primary neoplasms involving the innominate bone. J Bone Joint Surg Am. 1978;60:731-46.

15. D'Antonio JA, Capello WN, Borden LS, Bargar WL, Bierbaum BF, Boettcher WG, et al. Classification and management of acetabular abnormalities in total hip arthroplasty. Clin Orthop Relat Res. 1989;243:126-37.

16. Paprosky WG, Perona PG, Lawrence JM. Acetabular defect classification and surgical reconstruction in revision arthroplasty. A 6-year follow-up evaluation. J Arthroplasty. 1994;9:33-44.

17. Crowe JF, Mani VJ, Ranawat CS. Total hip replacement in congenital dislocation and dysplasia of the hip. J Bone Joint Surg Am. 1979;61:15-23.

18. Crowe JF, Mani VJ, Ranawat CS. Total hip replacement in congenital dislocation and dysplasia of the hip. J Bone Joint Surg Am. 1979;61:15-23.

19. Muller R. Bone microarchitecture assessment: current and future trends. Osteoporos Int. 2003;14:89-99.

20. Taddei F, Pancanti A, Viceconti M. An improved method for the automatic mapping of computed tomography numbers onto finite element models. Med Eng Phys. 2004;26:61-9.

21. Mirels H. Metastatic disease in long bones: A proposed scoring system for diagnosing impending pathologic fractures. 1989. Clin Orthop. 2003;415:256-64.

22. Damron TA, Mann KA. Fracture risk assessment and clinical decision making for patients with metastatic bone disease. J Orthop Res. 2020;38:1175-90.

23. Zhou Y, Min L, Liu Y, Shi R, Zhang W, Zhang H, et al. Finite element analysis of the pelvis after modular hemipelvicendoprosthesis reconstruction. Int Orthop. 2013;37:653-8. 
24. Ippolito J, Thomson J, Beebe K, Patterson F, Benevenia J. Outcomes following periacetabular tumor resection: A 25-year institutional experience. J Surg Oncol. 2020. doi:10.1002/jso.26088.

25. Angelini A, Drago G, Trovarelli G, Calabrò T, Ruggieri P. Infection after surgical resection for pelvic bone tumors: an analysis of 270 patients from one institution. Clin Orthop Relat Res. 2014;472:349-59.

26. Henderson ER, O'Connor MI, Ruggieri P, Windhager R, Funovics PT, Gibbons CL, et al. Classification of failure of limb salvage after reconstructive surgery for bone tumors: a modified system Including biological and expandable reconstructions. Bone Joint J. 2014;96-B:1436-40.

27. Ueda T, Kakunaga S, Takenaka S, Araki N, Yoshikawa H. Constrained total hip mega prosthesis for primary periacetabular tumors. Clin Orthop Relat Res. 2013;471:741-9.

28. Liang H, Ji T, Zhang Y, Wang Y, Guo W. Reconstraction with 3D-printed pelvic endoprostheses after resection of a pelvic tumor. Bone Joint J. 2017;99-B:267-75.

29. Wang B, Hao Y, Pu F, Jiang W, Shao Z. Computer-aided designed, three dimensional-printed hemipelvic prothesis for per-aetabular malignant bone tumor. Int Orthop. 2018;42:687-94.

\section{Tables}

Table 1 Pelvic model parameters

\begin{tabular}{|c|c|c|c|c|c|c|c|}
\hline Model & Type I & Type II & Type III & Type IV & Type V & Type VI & $\begin{array}{l}\text { Normal } \\
\text { pelvis }\end{array}$ \\
\hline Units & 205277 & 210649 & 206170 & 205739 & 208338 & 204499 & 204506 \\
\hline Nodes & 57205 & 58512 & 57613 & 57522 & 58051 & 57256 & 56913 \\
\hline $\begin{array}{l}\text { Minimum } \\
\text { unit } \\
\text { volume } \\
\left(\mathrm{mm}^{3}\right)\end{array}$ & 0.0003284 & 0.0003284 & 0.0003056 & 0.0003031 & 0.0004396 & 0.0002472 & 0.0004418 \\
\hline $\begin{array}{l}\text { Maximum } \\
\text { unit } \\
\text { volume } \\
\left(\mathrm{mm}^{3}\right)\end{array}$ & 780 & 1006 & 1090 & 1211 & 1075 & 1055 & 829 \\
\hline $\begin{array}{l}\text { Total } \\
\text { volume } \\
\left(\mathrm{mm}^{3}\right)\end{array}$ & 120604 & 125509 & 118827 & 118006 & 120459 & 115890 & 127133 \\
\hline
\end{tabular}

Table 2 General and follow-up data of the patients in the low risk noninvasive lesion group $(n=12)$ 


\begin{tabular}{|c|c|c|c|c|c|c|}
\hline $\begin{array}{l}\text { Sex/ } \\
\text { Age }\end{array}$ & Diagnosis & $\begin{array}{l}\text { Range of acetabular } \\
\text { involvement }\end{array}$ & $\begin{array}{l}\text { Follow-up time } \\
\text { (months) }\end{array}$ & $\begin{array}{l}\text { First } \\
\text { MSTS-93 }\end{array}$ & $\begin{array}{l}\text { Last } \\
\text { MSTS } \\
-93\end{array}$ & $\begin{array}{l}P \\
\text { value }\end{array}$ \\
\hline$M / 20$ & $\begin{array}{l}\text { Fibrous } \\
\text { dysplasia }\end{array}$ & $\begin{array}{l}50 \% \text { anterior column + } \\
\text { posterior column }\end{array}$ & 33 & 27 & 29 & \\
\hline$F / 26$ & Unknown & The anterior column & 27 & 29 & 30 & \\
\hline$M / 35$ & $\begin{array}{l}\text { Fibrous } \\
\text { dysplasia }\end{array}$ & Posterior column & 24 & 25 & 30 & \\
\hline$M / 18$ & Bone cyst & The anterior column & 42 & 27 & 29 & \\
\hline$F / 41$ & $\begin{array}{l}\text { Fibrous } \\
\text { dysplasia }\end{array}$ & Posterior column & 36 & 28 & 29 & \\
\hline$M / 26$ & Bone cyst & The anterior column & 39 & 26 & 28 & \\
\hline$F / 35$ & $\begin{array}{l}\text { Fibrous } \\
\text { dysplasia }\end{array}$ & $\begin{array}{l}50 \% \text { anterior column }+ \\
\text { posterior column }\end{array}$ & 28 & 24 & 27 & \\
\hline$M / 16$ & Bone cyst & The anterior column & 36 & 25 & 28 & \\
\hline$M / 36$ & $\begin{array}{l}\text { Fibrous } \\
\text { dysplasia }\end{array}$ & $\begin{array}{l}50 \% \text { anterior column + } \\
\text { posterior column }\end{array}$ & 33 & 29 & 30 & \\
\hline$M / 21$ & Bone cyst & $\begin{array}{l}50 \% \text { anterior column }+50 \% \\
\text { posterior column }\end{array}$ & 60 & 28 & 30 & \\
\hline$M / 45$ & Unknown & Posterior column & 24 & 27 & 30 & \\
\hline \multirow[t]{2}{*}{$F / 37$} & Unknown & Anterior column & 52 & 29 & 29 & \\
\hline & & & & $27.00 \pm 1.71$ & $\begin{array}{l}29.08 \pm \\
0.99\end{array}$ & 0.067 \\
\hline
\end{tabular}

Table 3 General and follow-up data of the patients in the low risk invasive lesion group $(n=7)$ 


\begin{tabular}{|c|c|c|c|c|c|c|c|c|}
\hline $\begin{array}{l}\text { Sex/ } \\
\text { Age }\end{array}$ & Diagnosis & $\begin{array}{l}\text { Range of } \\
\text { acetabular } \\
\text { involvement }\end{array}$ & $\begin{array}{l}\text { Operated } \\
\text { on or not }\end{array}$ & $\begin{array}{l}\text { Follow-up } \\
\text { time } \\
\text { (months) }\end{array}$ & Recurrence & $\begin{array}{l}\text { First } \\
\text { MSTS- } \\
93\end{array}$ & $\begin{array}{l}\text { Last } \\
\text { MSTS } \\
-93\end{array}$ & $\begin{array}{l}\mathrm{P} \\
\text { value }\end{array}$ \\
\hline$M / 23$ & $\begin{array}{l}\text { Giant cell } \\
\text { tumor }\end{array}$ & $\begin{array}{l}50 \% \text { anterior } \\
\text { column }+ \\
\text { posterior } \\
\text { column }\end{array}$ & $Y$ & 42 & $\mathrm{~N}$ & 24 & 27 & \\
\hline$F / 29$ & $\begin{array}{l}\text { Aneurysmal } \\
\text { bone cyst }\end{array}$ & $\begin{array}{l}\text { Posterior } \\
\text { column }\end{array}$ & $\mathrm{Y}$ & 27 & $\mathrm{~N}$ & 25 & 26 & \\
\hline$F / 31$ & $\begin{array}{l}\text { Giant cell } \\
\text { tumor }\end{array}$ & $\begin{array}{l}50 \% \text { anterior } \\
\text { column+ } 50 \% \\
\text { posterior } \\
\text { column }\end{array}$ & $\mathrm{Y}$ & 36 & $\mathrm{~N}$ & 24 & 30 & \\
\hline $\mathrm{M} / 22$ & $\begin{array}{l}\text { Aneurysmal } \\
\text { bone cyst }\end{array}$ & $\begin{array}{l}\text { Anterior } \\
\text { column }\end{array}$ & $\mathrm{Y}$ & 32 & $\mathrm{~N}$ & 28 & 29 & \\
\hline$M / 34$ & $\begin{array}{l}\text { Aneurysmal } \\
\text { bone cyst }\end{array}$ & $\begin{array}{l}50 \% \text { anterior } \\
\text { column }+ \\
\text { posterior } \\
\text { column }\end{array}$ & $\mathrm{Y}$ & 40 & $\mathrm{~N}$ & 26 & 29 & \\
\hline$M / 23$ & $\begin{array}{l}\text { Giant cell } \\
\text { tumor with } \\
\text { aneurysmal } \\
\text { bone cyst }\end{array}$ & $\begin{array}{l}\text { Posterior } \\
\text { column }\end{array}$ & $\mathrm{Y}$ & 67 & $\mathrm{Y}$ & 26 & 26 & \\
\hline \multirow[t]{2}{*}{ M/35 } & $\begin{array}{l}\text { Giant cell } \\
\text { tumor }\end{array}$ & $\begin{array}{l}50 \% \text { anterior } \\
\text { column+ } 50 \% \\
\text { posterior } \\
\text { column }\end{array}$ & $Y$ & 42 & $\mathrm{~N}$ & 24 & 28 & \\
\hline & & & & & & $\begin{array}{l}25.29 \\
\pm 1.50\end{array}$ & $\begin{array}{l}27.86 \\
\pm 1.57\end{array}$ & 0.009 \\
\hline
\end{tabular}

Table 4. General and follow-up data of the patients in the high risk of fracture group $(n=20)$ 


\begin{tabular}{|c|c|c|c|c|c|c|c|c|}
\hline $\begin{array}{l}\text { Sex/ } \\
\text { Age }\end{array}$ & Diagnosis & $\begin{array}{l}\text { Range of } \\
\text { acetabular } \\
\text { involvement }\end{array}$ & $\begin{array}{l}\text { Operated } \\
\text { on or not }\end{array}$ & $\begin{array}{l}\text { Follow- } \\
\text { up time } \\
\text { (months) }\end{array}$ & Recurrence & $\begin{array}{l}\text { First } \\
\text { MSTS- } \\
93\end{array}$ & $\begin{array}{l}\text { Last } \\
\text { MSTS } \\
-93\end{array}$ & $\begin{array}{l}P \\
\text { value }\end{array}$ \\
\hline $\mathrm{M} / 44$ & Giant cell tumor & $\begin{array}{l}\text { Anterior } \\
\text { column+ } \\
\text { posterior } \\
\text { column }\end{array}$ & Y & 33 & Y & 15 & 27 & \\
\hline $\mathrm{F} / 50$ & $\begin{array}{l}\text { Giant cell tumor } \\
\text { with aneurysmal } \\
\text { bone cyst }\end{array}$ & $\begin{array}{l}\text { Anterior } \\
\text { column+ } \\
\text { posterior } \\
\text { column }\end{array}$ & $\mathrm{Y}$ & 42 & $\mathrm{~N}$ & 12 & 23 & \\
\hline$M / 16$ & Fibrous dysplasia & $\begin{array}{l}\text { Anterior } \\
\text { column + } \\
50 \% \\
\text { posterior } \\
\text { column }\end{array}$ & $\mathrm{Y}$ & 24 & $\mathrm{~N}$ & 21 & 27 & \\
\hline $\mathrm{F} / 45$ & Fibrous dysplasia & $\begin{array}{l}\text { Anterior } \\
\text { column+ } \\
\text { posterior } \\
\text { column }\end{array}$ & Y & 36 & $\mathrm{~N}$ & 21 & 29 & \\
\hline$F / 14$ & Hemangioma & $\begin{array}{l}\text { Anterior } \\
\text { column+ } \\
\text { posterior } \\
\text { column }\end{array}$ & $\mathrm{Y}$ & 48 & $\mathrm{~N}$ & 17 & 28 & \\
\hline $\mathrm{M} / 25$ & $\begin{array}{l}\text { Aneurysmal bone } \\
\text { cyst }\end{array}$ & $\begin{array}{l}\text { Anterior } \\
\text { column+ } \\
\text { posterior } \\
\text { column }\end{array}$ & Y & 52 & $\mathrm{~N}$ & 19 & 27 & \\
\hline$M / 22$ & $\begin{array}{l}\text { Langerhans cell } \\
\text { dysplasia }\end{array}$ & $\begin{array}{l}\text { Anterior } \\
\text { column+ } \\
\text { posterior } \\
\text { column }\end{array}$ & Y & 60 & $\mathrm{~N}$ & 22 & 29 & \\
\hline$M / 41$ & $\begin{array}{l}\text { Giant cell tumor } \\
\text { with aneurysmal } \\
\text { bone cyst }\end{array}$ & $\begin{array}{l}\text { Anterior } \\
\text { column + } \\
50 \% \\
\text { posterior } \\
\text { column }\end{array}$ & $\mathrm{Y}$ & 36 & $\mathrm{~N}$ & 9 & 25 & \\
\hline M/31 & Fibrous dysplasia & $\begin{array}{l}\text { Anterior } \\
\text { column+ } \\
\text { posterior } \\
\text { column }\end{array}$ & Y & 28 & $\mathrm{~N}$ & 30 & 30 & \\
\hline$F / 51$ & $\begin{array}{l}\text { Diffuse giant cell } \\
\text { tumor of the } \\
\text { tendon sheath }\end{array}$ & $\begin{array}{l}\text { Anterior } \\
\text { column+ } \\
\text { posterior } \\
\text { column }\end{array}$ & Y & 56 & $\mathrm{~N}$ & 15 & 19 & \\
\hline$M / 49$ & Hemangioma & $\begin{array}{l}\text { Anterior } \\
\text { column + } \\
50 \% \\
\text { posterior } \\
\text { column }\end{array}$ & $\mathrm{Y}$ & 52 & $\mathrm{~N}$ & 12 & 27 & \\
\hline$F / 18$ & Chondroblastoma & $\begin{array}{l}\text { Anterior } \\
\text { column+ }\end{array}$ & $\mathrm{Y}$ & 49 & $\mathrm{~N}$ & 10 & 24 & \\
\hline
\end{tabular}




\begin{tabular}{|c|c|c|c|c|c|c|c|}
\hline & & $\begin{array}{l}\text { posterior } \\
\text { column }\end{array}$ & & & & & \\
\hline$M / 60$ & Fibrous dysplasia & $\begin{array}{l}\text { Anterior } \\
\text { column+ } \\
\text { posterior } \\
\text { column }\end{array}$ & $\mathrm{Y}$ & 26 & $\mathrm{~N}$ & 30 & 28 \\
\hline $\mathrm{F} / 40$ & $\begin{array}{l}\text { Aneurysmal bone } \\
\text { cyst }\end{array}$ & $\begin{array}{l}\text { Anterior } \\
\text { column + } \\
50 \% \\
\text { posterior } \\
\text { column }\end{array}$ & $\mathrm{Y}$ & 38 & $\mathrm{~N}$ & 19 & 12 \\
\hline $\mathrm{M} / 40$ & $\begin{array}{l}\text { Diffuse giant cell } \\
\text { tumor of the } \\
\text { tendon sheath }\end{array}$ & $\begin{array}{l}\text { Anterior } \\
\text { column+ } \\
\text { posterior } \\
\text { column }\end{array}$ & $\mathrm{Y}$ & 27 & $\mathrm{~N}$ & 18 & 28 \\
\hline$M / 34$ & Hemangioma & $\begin{array}{l}\text { Anterior } \\
\text { column+ } \\
\text { posterior } \\
\text { column }\end{array}$ & $\mathrm{Y}$ & 56 & $\mathrm{~N}$ & 25 & 28 \\
\hline$M / 44$ & Fibrous dysplasia & $\begin{array}{l}\text { Anterior } \\
\text { column+ } \\
\text { posterior } \\
\text { column }\end{array}$ & $\mathrm{Y}$ & 25 & $\mathrm{~N}$ & 30 & 30 \\
\hline$F / 42$ & Fibrous dysplasia & $\begin{array}{l}\text { Anterior } \\
\text { column + } \\
50 \% \\
\text { posterior } \\
\text { column }\end{array}$ & $\mathrm{Y}$ & 30 & $\mathrm{~N}$ & 26 & 30 \\
\hline$M / 44$ & $\begin{array}{l}\text { Aneurysmal bone } \\
\text { cyst }\end{array}$ & $\begin{array}{l}\text { Anterior } \\
\text { column+ } \\
\text { posterior } \\
\text { column }\end{array}$ & $\mathrm{Y}$ & 64 & $\mathrm{~N}$ & 24 & 30 \\
\hline$M / 38$ & $\begin{array}{l}\text { Giant cell tumor } \\
\text { with aneurysmal } \\
\text { bone cyst }\end{array}$ & $\begin{array}{l}\text { Anterior } \\
\text { column+ } \\
\text { posterior } \\
\text { column }\end{array}$ & $\mathrm{Y}$ & 40 & $\mathrm{~N}$ & 20 & 25 \\
\hline
\end{tabular}

\section{Figures}




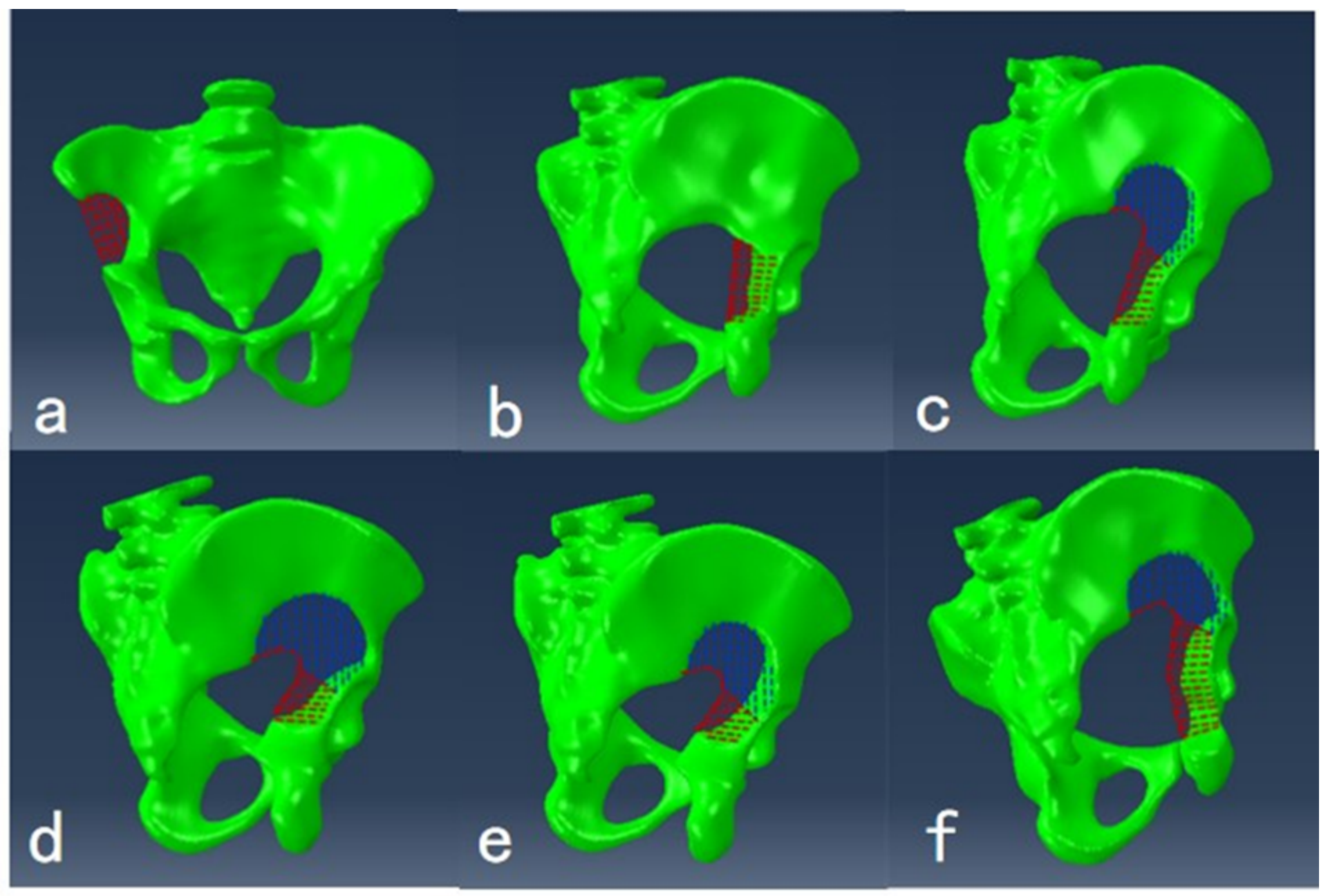

\section{Figure 1}

Six different types of periacetabular bone defect models were prepared using finite element analysis; the red part indicates the area of bone defect. a-f: types I-VI bone defect. 


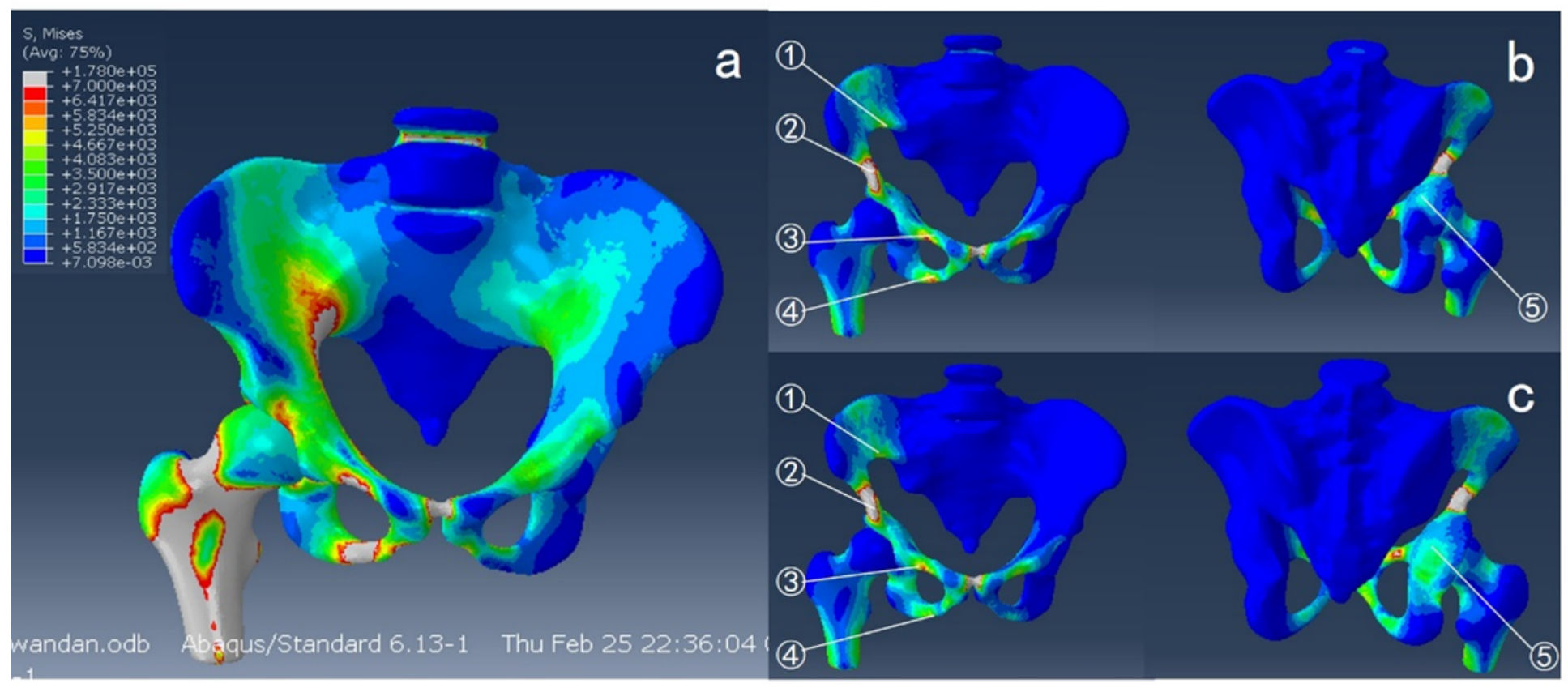

\section{Figure 2}

Finite element analysis was used to calculate the stress value of periacetabular bone in different states to predict the risk of fracture. a. Stress distribution of the normal pelvis in the affected one-legged jumping position. b. Stress distribution of the type $\mathrm{VI}$ bone defect model at $₫ 33.0 \mathrm{MPa}, \bigotimes 106.7 \mathrm{MPa}, \varangle 48.1 \mathrm{MPa}, \varangle 47.4 \mathrm{MPa}, \otimes 13.8 \mathrm{MPa}, \mathrm{c}$. $\otimes 17.8$

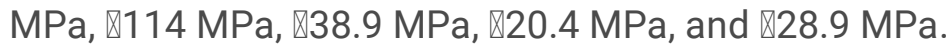

